\title{
TRANSLATION POLITICS IN ILOCANO- HAWAIIAN WRITING
}

\author{
Ma. Socorro Q. Perez \\ Department of English \\ Ateneo de Manila University \\ maperez@ateneo.edu
}

\begin{abstract}
The essay explains the translation process of three GUMIL Hawaii (Gunglo Dagiti Mannurat iti Ilocano ti Hawaii) Ilocano short fiction into English, as the receptor language. Three concerns come to configure in the deployment of postcolonial translation: first, that the exilic sensibility (concerned with rootlessness, departure, leave-takings, nostalgia, etc.) is addressed; second, that the materiality of Ilocano-Hawaiian diasporic culture as distinct from other Asian ethnicities in Hawaii and the Whites is clear; third, that the register of the original is approximated. The translation, therefore, offers a hybridized and syncretic Ilocano-Hawaiian English variety that is at once familiar, estranging and different.
\end{abstract}

\section{Keywords}

Diaspora, postcolonial translation, Ilocano-Hawaiian writing, Ilocano Hawaiian exilic sensibility, paratextual lens

\section{About the Author}

Ma. Socorro Q. Perez is an Assistant Professor of the English Department in Ateneo de Manila University. She earned her PhD in Comparative Literature at the University of the Philippines. She was awarded a Fulbright Research Grant in 2008, her affiliation of which was with the American Studies Department, University of Hawaii at Manoa. On that same year, she was also given a 6 month-visiting scholar affiliation with Asia/Pacific/American Studies at New York University. In April 2015 she will start a two-month Erasmus Mundus post doctoral stint with The American Studies Center of University of Heidelberg, Germany and The American Studies Center of University of Warsaw. Some essays published are the following: "Ilocano Immigrants' Renegotiation of Space in GUMIL Hawaii Writing (circa 8os)" (Kritika Kultura 10 [2008]); "Ilocano Writers of Hawaii: Invisible Stragglers" (Philippine Studies: Have We Gone Beyond St. Louis? [University of the Philippines Press, 2008]; “The Imbrication of Patriarchy, Racism, and 
Transnationalism and the Ensuing Gender Relations in Selected GUMIL Hawaii Short Fiction, circa 7os" (Asian Perspectives in the Arts and Humanities [2011]; and "GUMIL Hawaii Vision and Writing: Potentially Disenfranchising?" (Journal of the American Studies Association of the Philippines [2011]). She is the Coordinator of PhD English Language and Literature Program of Ateneo de Manila University. 
The consideration of works for translation project is informed by notions of class, race, and by canonical standards (i.e., national vis-à-vis regional or ethnic writing). Writings outside these rubrics remain in the periphery and often relegated to stark oblivion. The translation of the works by the writers themselves or by commissioning their works for translation is one way by which the possible extinction of marginalized writings may be averted. This, however, is not a common practice. Writers generally write in the language of their choice. Moreover, this does not resolve bigger issues of translation problems and politics.

We see a number of works rejected by commercial or academic presses, precisely because such writings are deemed a commercial risk, and in effect, largely bringing their invisibility. The wider reading public is not made aware of the existence of such writings, and by extension, has consequences on translation. If some works are adjudged not worthy of publication by presses or publishers, translation, as the "handmaiden" of the original is relegated to the backdoor. And if the original gets translated at all (especially those considered minority writings), these are works by well-meaning scholar-translators who have investments on both the original and the translation work. In other words, the possible translation of a beleaguered work is predicated by the politics of translation. It is in this state and condition that the translation process of three selected Ilocano Hawaiian works is caught in. This study explains the process involved in my translation of three GUMIL Hawaii (Gunglo Dagiti Mannurat iti Ilocano ti Hawaii) short fiction from Ilocano into English, as the receptor language.

Minority literature, such as those written in the vernacular, writings by grassroots sector, ethnic or regional writing, among others, are precisely, adjudged "minority," in relation to the national, and therefore, canonical literature. This binary between national writing (i.e., western canon), vis-à-vis ethnic writing (i.e., regional or vernacular writing), has established the status or standing of those deemed included in the literary canon: literature with a capital "L." Such dichotomies, have, to a large extent, sealed the marginal status of minority literature: literature with a small "l." The taxonomy of writings has consequences on works which may have potential for translation, nullifying the promise of "crossing" borderlands.

This is the beleaguered fate of Ilocano-Hawaiian writing, or more broadly, Filipino- American writing in the US. The absence of published Filipino-American writing and Philippine vernacular writing in the 1970 s had been decried by critics such as Marcelino Foronda and Oscar Peñaranda. The latter asserts that the absence of Filipino American writing is a "literary genocide" (xi). The great Filipino critic/scholar, E. San Juan, Jr. points out that in the 1982 MLA (Modern Language Association) survey of Three American Literatures (ed. Houston Baker Jr.), the Asian American section includes only Chinese and Japanese authors (441). This omission is repeated in the 1990 MLA reference guide, Redefining American Literary History, where a brief mention is made of Filipino writing in a meager bibliographic list under the rubric Philippine American Literature. Finally, in the book, Charlie Chan

Kritika Kultura 24 (2015): -261 
is Dead 2 At Home in the World: An Anthology of Contemporary Asian American Fiction (1993) (ed. Jessica Hagedorn, and reprinted after 10 years), Hagedorn asserts that this anthology is considered a milestone in Asian American writing. In the Introduction, Hagedorn declares that the anthology is a belated representation of Asian American writing, particularly in Filipino American literature (xxviii- xxxii). But while Filipino American writing in English is now included, one notes the stark absence of Philippine vernacular writings within the Asian American frame. Specifically, there is no mention of the existence of Ilocano-Hawaiian (an ethnolinguistic group from the Northern part of the Philippines) Literature within this broad archipelagic Asian American and Filipino American literary frame.

The non-inclusion of Ilocano-Hawaiian diasporic writings in Filipino-American writings does not give a true picture of Filipino American literature, especially given the fact that the Filipino population in the US has been steadily rising and has crucially contributed to America as a huge industrial force. According to Erlinda Kravetz, the Filipinos "makeup one of the largest pieces of this huge, colorful quilt that is the American nation" (ix). The marginalization or absence of IlocanoHawaiian writings in Filipino-American anthologies and more broadly, AsianAmerican literature, and consequently, and by extension, the dearth or absence of translated works, illustrates notions of class, ethnicity, and canonical writing.

The particular contour that Ilocano-Hawaiian writing and discourse has taken is shaped by the Ilocano immigrants' constitution by dominant US hegemonic forces and racializing immigration policies and practices. The writings gesture towards the assertion of "Ilocano-Hawaiian diasporic identity." It is recuperated as a signifier of Ilocano-Hawaiian representation that contends with and counters the "spectre of institutional invisibility" (Tiongson 14). Thus, following the Ilocano-Hawaiian vision of self-representation, this essay on my translation of three selected GUMIL Hawaii short stories aims to explain the process and decisions that informed my translation work. For instance, my translation deploys both the recuperative power of postcolonial translation and paratextual lens in order to foreground the specificities of Ilocano-Hawaiian diasporic literature, language, culture, and identity, that is informed and complicated by the oscillation of transnational spaces, border crossings, and porosity in this age of globalization, changing and enriching altogether, the terrain of Asian American literature, specifically, Filipino American writing.

\section{SETTING UP THE GEOPOLITICAL TERRAIN}

There is nothing vapid or empty in the task of translation. It should interrogate the "vagaries and vicissitudes of the exercise of power in a society, and what the exercise of power means in terms of the production of culture, of which the production of translations is a part" (Tymoczko 5). Such an assertion nullifies the common notion

Kritika Kultura 24 (2015): -261

(C) Ateneo de Manila University

<http://kritikakultura.ateneo.net> 
that translation is transparent, entailing a one to one correspondence between the source language and the receiving language. Imperative, therefore, in translation work is looking into the specificities of historical forces and the dialectics of discourses that determine the contours of cultural practices and the complex consequences that come out from this interplay. Failure to ground the relationships of discourses in a translation becomes mere aesthetics. The interest of my study is to interrogate the imbrication of historical forces and the geopolitics involved that have constituted and spurred Filipino migration and diaspora to the United States, particularly the Ilocanos to Hawaii. Such historic-political relationships, therefore, have engendered Ilocano-Hawaiian writing, and in turn, inform the task of translating diasporic Ilocano-Hawaiian writing, particularly, GUMIL Hawaii.

The contemporary phenomenon of globalization or transnational flow of global market and global circuiting of goods and products has engendered radical consequences on the people's way of life, one of which is "hypermobility" or the speed and intensity of exchange of information, goods, services, in ways that were hitherto unimaginable. Borders and boundaries heretofore, perceived as physically real and tangible have become porous and in danger of disappearing. People are uprooted from their old countries and from familiar grounds, yielding shifts in identities. The globalized turn of the contemporary condition has brought in a great number of Filipinos, particularly the Ilocanos to Hawaii. The phenomenon of diaspora has compelled the Ilocano-Hawaiian community to negotiate this condition of displacement through narrative-making. Necessarily, the task of translating Ilocano-Hawaiian literature, specifically, GUMIL Hawaii writing is informed by the interrogation of historical forces and their imbrication with other complex forces and pressures in Hawaii as a host land of migration and settlement and how they impinge on the lives of the diaspora Ilocano-Hawaiian community.

The presence of the Filipinos in Hawaii goes back to the American annexation of the Philippines in 1898, which marked the beginning of a long-standing "relationship" between US and the Philippines. At around such time, Hawaii, an expanding capitalist economy and a huge producer of sugar, had also been annexed as a territory of the US ${ }^{1}$ The sugar economic industry in its transnational logic of capital demanded and relied upon the migration of labor to man the sugar plantation fields of Hawaii. Since the Philippines was a colony of the US, such colonial status had rendered the latter license to transport Filipinos to Hawaii as US nationals. In 1906, the first batch of fifteen recruits from the Ilocos region, arrived in Hawaii as plantation laborers, This began the large-scale Filipino migration to Hawaii. By 1945, there was an estimate of 129 ,ooo Filipino arrivals in Hawaii (Teodoro 12). While they were US nationals in the technical sense of the term, they were treated as mere contract workers (San Juan 446; Cordova 30). The Filipinos entered the U.S. as "colonized 'nationals' - neither citizens nor aliens-mainly as contract workers" (San Juan 31). Such an anomalous classification of the Filipino plantation laborers in Hawaii, did not merit "wards" of the US status, depriving

Kritika Kultura 24 (2015): -261 
them of the rights accorded to any American citizen. Their status as mere contract workers made them vulnerable to the US laws. Steadily, throughout the growth and expansion of Hawaii's sugar industry, the Philippines became one of the largest exporters of cheap labor. The circulation of US capital and its imperial economic imperatives fueled the migration of Filipinos to Hawaii and the US and their ensuing identity production as cheap labor that is constituted in a complex, private, public transnational practices and relationship between the Philippines and the US.

But with the inroads of global economy which demanded the withdrawal of protective tariffs in the 1960s, Hawaii saw the decline of the sugar plantation industry. Cheaper cost of sugar from overseas penetrating the broader US market consequently saw the eventual collapse of Hawaii's sugar industry. This development threatened the main source of livelihood for most of the Filipinos, specifically the Ilocanos, as they were the largest number of plantation group that came to Hawaii. Tourism emerged as the new industry of Hawaii. According to Dean Alegado, "thousands of workers were forced to look elsewhere for jobs in the emerging tourism industry-the hotels, golf courses, restaurants and construction sites" (22). They were compelled to move out of plantation communities, relocating to urban areas where more job opportunities could be found.

The phenomenal growth of the tourism industry in Hawaii required a huge labor. The tourist industry opened up jobs not only in the service sector, such as cleaning and food preparation but spurred the growth of related industries, such as airlines, hotels, tour services, restaurant, and the support business (The Shaping of Modern Hawaiian History: Hawaii Today and Tomorrow." Unit V. Honolulu: Hawaii Multicultural Project, 55). Jobs in Hawaii's tourism industry became the "new plantation." Moreover, the passage of the 1965 US Immigration Act or Family Reunification Act at this particular historical juncture was most timely. While it brought in the families of the plantation laborers as well as professionals, skilled and unskilled labor, jobs in demand were in tourism's service sector. The number of Asian immigrants to Hawaii and the US Mainland was unprecedented. While the 1965 Immigration Act was purportedly ratified for the reunification of families, the new Immigration Act was a brilliant maneuver that brought in the needed labor to populate the service sector of the tourism industry; and while the immigrants may have different reasons for settling in the US, the new immigrants would have to seek employment at some point. As jobs in demand were in the service sector of the tourism industry, the plan was to integrate the new immigrants into the potential tourism labor force and for them to be considered in employment needs projectives (45-46).

Though the Filipino immigrants rank third in the number of population in Hawaii, the number doesn't add up to visibility. This "pall of invisibility" is anchored on historical postulates, a grave consequence of colonial and neo-colonial relationship with the US, rendering the Filipino immigrants susceptible to the vagaries of (neo) colonial US-Philippine relationship (Gonzales and Campomanes 82). The spectre 
of invisibility is a "historic consequence of US colonial dispossession and as the defining condition for the globally itinerant and indeterminate production of a Filipino nationality or national culture" (Gonzales and Campomanes 82). The large majority of Filipino immigrants to Hawaii were conscripted into the tourism labor industry, thus, defining Filipino subjectivity, as labor, vis-à-vis, US as an empire of capital. Moreover, this US-centric historical, economic, and political practices and ideologies have continued to displace and to alienate the Filipino migrant in a complex and overdetermined way (San Juan 183).

GUMIL Hawaii comes from a long-time tradition of Ilocano writers' attempt at organizing themselves into one body with unified and articulated goals, one of which is the development and growth of Ilocano literature, language, and culture. ${ }^{2}$ Although this association, as other chapters subscribes to the Constitution and By Laws of the GUMIL Filipinas, the specificity of context inevitably comes in. GUMIL Hawaii is precisely born from a diasporic need and consciousness. Its narratives and the direction of its discourse speak of border crossings, departures, returns, nostalgia, the construction of "home," and shifts in identities.

The contemporary phenomenon of systematic dispersal of hundreds and thousands of Filipinos to all parts of the globe is unstoppable. Annually, an average of forty thousand immigrants settle in mainland US alone, and 4,000 settle in Hawaii. This contemporary dislocatory condition may induce a type of "schizophrenia" triggered by the shift of identities. Moreover, local pressures, such as the racializing practices of the US render an anxiety on the immigrant exile. An attempt at resolving the deterritorialized condition of the Filipino immigrants, particularly the Ilocano-Hawaiian immigrants is through writing. Through the discourse of narrative-making, particularly through writing, they not only temporarily negotiate this nostalgia and achieve an "imaginary coherence" (Hall 394 ) but has provided a space and an agency to perform their "Ilocanoness."

This currency for roots, origin, and authenticity observed in GUMIL Hawaii writing comes from somewhere. It is informed by discriminatory and exclusionary US immigration practices and regulatory norms, thus, the impulse is to seek the familiar. Anything that is associated with "home" or the Motherland is deemed desirable as this affirms their Ilocano "identity," giving the immigrants a symbolic semblance of coherence and stability, in spite of the diasporic condition. The legacy of history, memories, and relations with the Ilokandia homeland vis-a-vis the demands and pressures of settling in the new location intersect in the construction of an Ilocano-Hawaiian diasporic writing and identity. Ilocano-Hawaiian writing is largely exilic in ethos, pointing to a "fictive" Ilokandia homeland. Their literature does not only speak of memories and remembrances of home but of their deterritorialization, alienation, rootlessness, absence, and invisibility. Following Campomanes, Ilocano-Hawaiian diasporic writing thematizes "a perennial sense of displacement and intractable identity crisis" (82).

Kritika Kultura 24 (2015): -261

(C) Ateneo de Manila University

<http://kritikakultura.ateneo.net> 


\section{LAYING DOWN THE POSTCOLONIAL TRANSLATION FRAMEWORK}

One traditional assumption of translation is approaching the text as a "sacred" document. Given this assumption, the translator is tasked to find a full equivalent of the words or sentences, careful that no transgressions occur. Since a "perfect homology is impossible between translation and source (Tymoczko 23), coming from the notion that the translation must be absolute, renders the translator in a most frustrating position. Such understanding of translation is overly narrow, limiting the translation task to the realm of linguistics. Lawrence Venuti asserts that limiting translation to the realm of linguistics brackets the social and cultural factors that inevitably come into play in the translation process (2). The overriding concern for linguistic equivalence elides material differences of culture. It succeeds only in "obscuring and muting cultural disjunctions (Tymoczko 21). Carol Maier points out that such assumption "not only misrepresent[s] but actually distort[s] the activity of translation" (21). Maier explains that a misrepresentation is committed, precisely because of the "suppression of the inevitable differences that occur between languages, races, culture" (24) Venuti asserts that the translation act should be understood less as an engagement of achieving a "unified meaning in individual source texts and more to the long chain of multiple meanings and the pluralities of language that lie behind any textual construct" (6). Translation is concerned with the assertion and foregrounding of difference, especially for the peripheralized discourses and culture.

Following Maria Tymoczko, the primary difference between a postcolonial translator and an ordinary translator is in the task that they are confronted with. The translator transposes the text, while the postcolonial translator transposes the culture. The whole category of "culture" is to be understood not only as a "language, a cognitive system, literature (comprised of a system of texts, genres, tale types, and so on)," but more crucially, the category should be understood as the "material culture, a social system and legal framework, a history"(20). A literary translation is "de facto concerned with differences not just in language (a mechanical transposition of words and sentences), but with the same range of cultural factors that a writer must address when writing to a receiving audience composed partially or primarily of people from different culture" (Tymoczko 21). The task therefore, of a postcolonial translator is similar to the postcolonial writer in the valorization of cultural differences, particularly in lending agency to a minority and a peripheralized culture. More crucially, a postcolonial translator is concerned with "penetrating reified world views particularly in the West to allow real cultural difference to enter" (Tymoczko 21). In other words, the task of a postcolonial translator is foregrounding the suppressed voices and discourses. Translation should be understood as a "site for cultural production, the space where 'newness' enters the world" (Bhabha qtd. in Tymoczko 21). Postcolonial translation, therefore, is concerned with the articulation of difference and attaining questions of agency

Kritika Kultura 24 (2015): -261

(C) Ateneo de Manila University

<http://kritikakultura.ateneo.net> 
in effecting cultural change. The agenda, therefore, of the postcolonial translator is political. The postcolonial translator works primarily to challenge, subvert, and redefine the dominant notions of translation which are underpinned by western, hegemonic or universalist norms. Moreover, the postcolonial translator insists on a "new language that defies the notion that a 'foreign' text can be readily translatable into another language" (Mehrez 121). The postcolonial translator is informed by the notion that the "language of the other comes to encode messages which are not readily decoded by the monolingual reader whose referential world continues to exclude, ignore, and deny the existence of other referential worlds that are crucial to a more global rather than a colonialist, 'imperialist' reading of the text" (Mehrez 122). Therefore, the discourse that informs the practice of a postcolonial translator is a movement through the "space 'between' languages" (Maier 22), or to "create a language 'in between' and therefore come to occupy a space 'in between"” (Mehrez 121). In turn, this "in between" space is the appropriated space that the postcolonial translator is able to recuperate. The act of translating into another language involves the "exchange process of language itself" (Ortega 293), which ironically, enables the emergence of a language borne by the "in betweenness," or by extension, a new "language."

Thus, following the assertions above, three concerns come to configure in my deployment of postcolonial translation of selected GUMIL Hawaii short fiction: first, that the exilic sensibility (concerned with rootlessness, departure, leave-takings, nostalgia, etc.) is addressed; second, that the materiality of Ilocano-Hawaiian disporic culture as distinct from other Asian ethnicities in Hawaii and the Whites is clear; third, that the register of the original is approximated.

While the Ilocano-Hawaiian writing uses a classical formal, even preternaturally poetic language, my translation, in turn, approximates this formal register, hewing close to the tenor and sensibility of the original in the narration part of the stories. The dialogue is another concern. Since speeches and utterances have a certain temporality, they take on a certain urgency and immediacy. Such characteristic of utterances render on them a powerful space for negotiation. In other words, through the translation of the dialogue of the characters, my translation opens up a space for bringing in a distinct Ilocano-Hawaiian English, that is unmistakably Ilocano-Hawaiian English in its register and inflection. The reader, in turn, detects that the translated speeches are not utterances of a native English speaker. The move away from the idiom of American English aims at defamiliarization. The Englishspeaking readers are looped into the dialectics of Ilocano-Hawaiian condition and materiality. The postcolonial translation, therefore, offers a hybridized and syncretic Ilocano-Hawaiian English that is at once familiar and estranging and different.

Kritika Kultura 24 (2015): -261 


\section{USE OF PARATEXTUAL METHOD: ANALYSIS OF SHORT FICTION}

The three stories are translated from Ilocano language into the English, the receptor language. As delineated in the earlier section of my study, the relationship between the Philippines and the US has been equilibrated by a primal colonial apparatus. Though the US colonial regime had officially lasted for only 50 years, it has had great implications on the subjectification of the Filipinos. It is through this hierarchical relationship that had rendered the US the license to recruit Filipino cheap labor to Hawaii as plantation laborers. This asymmetrical relationship is further entrenched by the transformation of Hawaii into a huge tourism industry which opened up jobs in the service sector. The plan was to integrate the new immigrants into potential labor force. The structural integration of Filipinos into the wider sectors of the US economy, has in turn, deepened the unequal relationship between Filipinos and the US. The green card and the badge or stamp of a US citizen is awarded to the Filipino immigrant at the expense of subsuming the ethnic country of origin to take on the national US citizen status. In other words, the Filipino immigrant practically drops his Filipino citizenship in order to take on the US national citizenship status and identity. Thus, the allegiance to US laws and regulatory norms is expected of the US citizen. It is these pressures and conditions that the Filipino immigrant is expected to identify with if $\mathrm{s} /$ he were to be a holder of the green card and eventually, be granted the US citizenship. Thus, the decision to write in Ilocano by the GUMIL Hawaii writers comes not just out of the need to preserve their history, language, literature and culture, it is a decision inflected by the vagaries and dictates of Hawaii and more broadly, US.

The translation of selected Ilocano-Hawaiian short stories into English speaks back at the empire. My translation and substantiated by paratextual lens are acts of appropriating the English language to portray and expose the diasporic consciousness of the Ilocano-Hawaiian immigrants, and whose experience of diaspora is shaped by US transnational logic and racializing immigration policies and regulatory norms. My translation strikes back at the US empire by departing from the "standard" or "correct" English, refracting the monolithic claims of English as the imperial language in order to wrestle in an Ilocano-Hawaiian English, rendering, in turn, a new way of seeing and perceiving reality that is apprehended by the translation's appropriation of the English language.

The stories which I translated are the following: "The Heaven of Nana Sela" ("Ti Langit ni Nana Sela"[1980]) by Pelagio Halaba, "The Seaweed Pickers" ("Ti Agpidpidut ti Limo [1981]) by Amado Yoro, and "The Tang of Yesterday's Rain" ("Naapgad ti Arbis di Kalman" [1983]) by Artemio Ignacio. These three stories are all award-winning under the category of short story ("sarita") writing. They are drawn from Dawa (1989), an anthology of winning entries of short fiction and drama from 1980-1984. GUMIL Hawaii organizes an annual writing competition on the genres

of poetry, drama, and short story. The judges of the writing competition come

Kritika Kultura 24 (2015): -261

(C) Ateneo de Manila University

<http://kritikakultura.ateneo.net> 
from the roster of older, more experienced GUMIL Hawaii writers, themselves. The winners, in turn, are included in GUMIL Hawaii anthologies, which are published by the Association itself. ${ }^{3}$

Included in the Dawa anthology are 18 shortstories with the following contributors and the number of entries: Amado Yoro (4), Mario Albalos (3), Artemio Ignacio (4), Elizabeth Madarang (2), and one entry each from the other four contributors (Carlo Laforga, Cresencia Alcantara, Marcelo Tablizo, and Reynaldo Dugue) including Pelagio Halaba, who wrote "The Heaven of Nana Sela" which is one of the stories translated. Although the selections are all adjudged first, second, and third placers, the choice of selection is primarily based on stories that dramatize the different experiences that the protagonists as Ilocano- Hawaiian immigrants are confronted with. I did not choose stories that contain some dreamlike elements, like the other stories of Amado Yoro, or stories that are largely set in the Philippines (for instance, characters about to depart for a short visit to Hawaii or are about to immigrate to Hawaii), particularly in the Ilocos region (works of Madarang, Duque, Tablizo). They were not chosen since the primary objective of the translation is to foreground the exilic experiences of the Ilocano-Hawaiian immigrants and their negotiation of this condition. Though written in different years (from 1980-1984), these stories come to intersect in their thematization of the characters' exilic sensibility. In other words, the short fiction selected for translation strongly illustrates the different issues a diasporic community, such as Ilocano-Hawaiian immigrant exile, contends with. Though these stories were written in different years, the stories resonate with narratives of exile, diaspora, nostalgia, and reterritorialization.

Besides elucidating this nostalgia for "home" (referring to Ilokandia home) and their re/negotiation of this condition, my translation project foregrounds their marginality. Employing a postcolonial framework allows the valorization of IlocanoHawaiian writings classified under "others" by western, hegemonic norms of seeing and writing, and therefore, institutionally invisible. Moreover, in my translation of three Ilocano-Hawaiian short fiction into English, the project of a postcolonial translation foregrounds the method of "paratextual material" around which the Ilocano-Hawaiian diaspora is constituted. The particular "paratextual" discourse (which works like a preface to the translation work) is recuperated as a necessary companion piece to the translation. It valorizes the dislocatory condition of the Ilocano-Hawaiian immigrant-protagonists. My postcolonial translation analysis also includes the ways by which the Ilocano immigrants work at reterritorializing their diasporic condition. Since the exilic pathos caused by the global dispersal of Filipinos permeates in the Ilocano-Hawaiian writing, the postcolonial translation attempts to foreground that sensibility and condition. Such strategy is meant to valorize the particularities and pressures surrounding Ilocano-Hawaiian diasporic condition as reflected in their writing. 
"The Heaven of Nana Sela" (“Ti Langit ni Nana Sela”) by Pelagio Halaba, is about a grandmother who has been in Hawaii for three years now. She lives with her son and his family. Nana Sela babysits her two pre-school grandchildren. Throughout the story, she is gripped with an unmitigating nostalgia ("iliw") and this yearning to return home to her hometown (purok) in the Philippines. She asks her son, Jim, a couple of times to allow her to go home, but each time, she is rebuffed. Her inability to speak and understand English and her ignorance of the ways of international travel are some reasons her son would not allow her to travel back to the Philippines on her own. Later, she overhears in a conversation between her son and his wife that Nana Sela could not go home just yet for a visit, as the kids would be left without a nanny.

This exilic condition or displacement that Nana Sela feels in a strange country is intensified by her inarticulateness. Her inability to speak and understand English cuts her from belonging to the place. This intensifies her isolation, incarcerating her all the more in this paradise-like Hawaii. It is precisely this inability to speak English that Jim uses to explain to his mother why he could not allow her to go home alone.

Nana Sela, however, attempts to dispel this dislocation by prefiguring in her mind, in her imagination, her Ilokandia homeland which she revisits each time she is in the middle of a housework, in the privacy of her room, or when she is alone. When her son's unyielding stance finally sinks in, she tries to negotiate this yearning for home by constructing a fictive home. Thus, in her interior monologue, she rationalizes that Hawaii and the Philippines have much in common, anyway, recognizing the presence of many fellow Ilocanos. She also observes that many vegetables found in Hawaii are also raised and produced in the Philippines. Moreover, Nana Sela resolves to make Hawaii a more habitable place to live in by constructing a vegetable garden, planting vegetables (eggplant, camote tops, malunggay tree, etc.) that are also found in her Ilokandia yard. The vegetable garden approximates her Ilokandia homeland. The act of reconstructing a vegetable garden is not just an empty activity to assuage her loneliness, more crucially, it is a creative expression that attempts to sublimate the literal and figural paralysis that Nana Sela is gripped in-a consequence of her displacement.

Finally, Nana Sela's friendship with Nana Clara, a newfound friend, is valuable because the latter is also an Ilocana. Nana Clara, therefore, can be considered as a signifier of an Ilokandia past that satisfies, albeit temporarily, Nana Sela's need for a physical return to one's originary home. Thus, she looks forward to Sunday masses because she is able to meet up with her townsmate friend, Nana Clara. As the friendship is grounded on their hometown ties (kailyan or kababayan), this, in turn, renders an "imaginary coherence" to the figural and literal inarticulateness, isolation, and alienation that Nana Sela is experiencing in edenic Hawaii.

Kritika Kultura 24 (2015): -261

(C) Ateneo de Manila University

<http://kritikakultura.ateneo.net> 
The next story valorizes the dislocation through the disjunction of values between the characters. In “The Tang of Yesterday's Rain” ("Naapgad ti Arbis di Kalman") by Artemio T. Ignacio, Manuel, the protagonist, has been in Hawaii for two years now. He has finalized plans to go home to the Philippines for a visit. He is scheduled to fly in three days' time. However, for some time now, Manuel notices that Lucy, his older sister, has not been talking to him. Manuel, on the other hand, does not understand the sister's change in her actuations towards him. He learns later in an ugly confrontation with Lucy that he needs to pay for everything that he owes her, including his schooling and his plane fare to Hawaii. In the end, he cancels his trip to the Philippines, and the little savings which he is reserving for his trip home is given to his sister, instead, as his initial payment for what he owes her.

Manuel's two year sojourn in Hawaii, so far, has been made bearable by the promise of a return to the Philippines. There is always a looking back to his hometown. Often, thoughts of home intrude: "Do fishes in Pandan River still abound? What could my friends be doing now? Has my girlfriend changed, Is she more beautiful?" These thoughts and images fuel his desire to go home and at the same time make his stay in Hawaii more bearable. His memories of home excite him and give him a sense of moorings in his literal displacement. This physical dislocation, however, is transformed into a symbolic homelessness and dislocation by the severance of sibling ties over money matters. Lucy bluntly tells Manuel to move out after his return from the Philippines. Manuel is stunned by Lucy's coldheartedness. In the altercation between the siblings, he reminds Lucy that they are family, who in turn, retorts that there are no blood ties in Hawaii. (Awan kinabsattan ditoy. Hawaii detoy.) In other words, now that he has found a job, Manuel's first responsibility is to pay his debts and obligations. Manuel's literal and physical dislocation is deepened by the severance of ties between siblings. While this first level of displacement (being away from the Philippines) is supposedly mitigated by the presence of a family in Hawaii, the value accorded to independence, paying up debts are reasons that cause the severance of family ties. Thus, with family ties broken, Manuel experiences both literal and symbolic homelessness and dislocation. Lucy's identification with the values of modern, white ideal, such as independence, practicality and her denigration of the importance of family bonds, deemed an important Filipino value, is supplanted. Lucy points out that in Hawaii, there is no place for sentimentality, kinship/ family and hometown ties-values which Manuel upholds. Lucy serves as a foil to Manuel. She has been in Hawaii far longer than Manuel and is shown identifying with the modern, American middleclass values. Manuel, on the other hand, remains steadfast to unchanging Filipino ideals. The differences in their regard of such values cause the severance of ties between the siblings. Manuel is confronted with American regulatory ideals which his sister identifies with, and by extension, her disidentification of Filipino values.

Kritika Kultura 24 (2015): -261 
The last story, "The Seaweed Pickers" ("Dagiti Agpipidut ti Limo") by Amado I. Yoro, illustrates generational conflict between the elders and the young, parents and children. In the story, Manang Consuelo, a widow, tries to meet the needs of her family of four by gathering seaweeds in a nearby sea and selling them to Filipino buyers and to a few Japanese and Chinese stores. The difficulty of picking and selling seaweeds as a source of income comes from a fierce competition with other Filipinos. This difficulty is compounded by her problem with her two teenage children who have acquired modern American values and have given her nothing but problems. What compounds the challenge of a single parent and the greater source of the protagonist's dislocation is borne out of differences between her and her two teenage children. She worries about their "American" ways and their disidentification of Filipino values. Manang Consuelo attempts to negotiate her dislocation (the precariousness of her source of income and disintegration of family values and family unity in her home) by insisting that such traditional Filipino values (referred to in the story as the "Maria Clara" values) are kept paramount and must be observed by her children. But her children's disidentification of their "Filipinoness" is the source of this conflict between these two generations. In her rumination, Consuelo reconstructs a fictive, "Maria Clara" past that is enshrined in a Filipino-American family. Given this deterritorialized condition, her consolation is looking back to a fictive homeland, giving her a sense of moorings and strength. On the other hand, the presence of Ka Conrado, an Ilocano suitor who continues to observe Filipino traits and values, provides hope for Manang Consuelo. He promises to act as a father-figure to her errant children. Providing strength in each other, Consuela and Conrado come together to re/negotiate this exilic condition and displacement in Hawaii.

The sense of nostalgia that informs Ilocano-Hawaiian/GUMIL Hawaii narratives and definitional ceremonies is not just some pure or empty sentiment but firstly and primarily, a survival strategy, a coping mechanism against the diasporic condition and the hostility of US hegemonic forces. Secondly, the nostalgia that underpins Ilocano-Hawaiian diasporic writing in which, the Ilokandia Motherland is enshrined at the center renders "schizoid or split" subjectivities a symbolic or an imaginary coherence. The sense of nostalgia which is a longing for one's home and everything associated with it is a signifier that goads the immigrant to do well. The commitment and responsibility to one's family and Ilokandia "country" and the hope of a return (given the impossibility of one's return, as time and history have intervened, and the experience of movement has changed the immigrant) is kept strong through memories. Finally, Ilocano-Hawaiian diasporic writing or GUMIL Hawaii writing recuperates/refunctions the category of nostalgia to forge a community. The strength of the Ilocano-Hawaiian community comes from this predisposition that is sutured by a common memory, common frame of reference. The act of looking back to one's Ilokandia Motherland is a recognition of where 
Ilocano-Hawaiian immigrants all began, in turn, inspiring them to forge dreams and hopes and the resolve to do well in a multiethnic, highly competitive Hawaii.

\section{THE POSTCOLONIAL TRANSLATION PROCESS}

The act of translation is not easy as this entails a simultaneous crossing over and the synthesis of two languages and cultures. Moreover, the overdetermined character of meaning causes the translation process to spill off into different directions. Thus, the source text can never be entirely pinned down by the translation. Conversely, the receiving language and culture by its own modes, forms, and features may conspire to determine its own readings and meanings of the translated texts, "shaping and extending possible interpretations of the translation in directions other than those inherent in the source text" (Tymoczko 199). Consequently, translators are impelled to make some choices, decisions on what to foreground, take out, and deemphasize. Often, the set of decisions and choices made by the translator is a conscious act, meant to create representations of the source text which are characterized as inevitably "partial." This partial character of translation inevitably makes the act of translation " partisan," rendering the translation act as "engaged and committed, either implicitly or explicitly" (Tymoczko 199). The representations done on the source text which are determined by the translator's choices and decisions may vary. The representations can come in a form of linguistic manipulation, such as word by word, or demonstrated by the use of paratextual materials that surround translations. Such paratextual materials include introduction, footnotes, reviews, literary criticism, etc. (Tymoczko 199).

In the translation of selected GUMIL Hawaii short fiction, my deployment of paratextual material, as shown above, is a postcolonial translator's decision that aims to foreground the exilic condition of the Ilocano-Hawaiian characterimmigrants and their way of reterritorializing this dislocatory condition. IlocanoHawaiian diasporic writing is classified under ethnic minority writing. The spectre of invisibility that it contends with is in its non-representation in Filipino American writing and Asian American literature. The decision on the part of the IlocanoHawaiian writers to use the Ilocano language is political and ideological. It is an assertion of difference and self-representation in a multiethnic state, and this has to be foregrounded in the translation act. While Filipinos in Hawaii are subjected to broader US hegemonic norms, they also find themselves in strong contention with other Asian ethnicities. The task of translation is to bring into visibility the interplay of forces that constitute this diasporic space that contextualizes IlocanoHawaiian culture and writing. Moreover, an objective in the transposition of the Ilocano-Hawaiian texts is to bring into the readers' consciousness the contours of an Ilocano-Hawaiian culture that is distinct from other ethnicities and the whites.

Kritika Kultura 24 (2015): -261 
Observed in the translation is adeeply-ingrained custom or practice amongst the Ilocanos in its use of honorifics (manong, manang, ading, nana, ka). Honorifics do not only serve to confer or convey titles or distinctions, but their use is meant to distinguish age difference: manang (older sister), manong (older brother); ading (a younger person in reference to an older person). Moreover, honorifics is used to show respect for the person spoken to. Such examples of honorifics are used extensively in the three stories. Keeping them in the translation not only stems from the absence of an equivalence in English, illustrating the untranslatability of foreign texts, in this case, Ilocano, the source language but this set of "untranslatables" belies the notion that a foreign text is readily translatable into another language. The notion of easy translatability of foreign texts is subverted in the translation. The titles "Nana" (older woman) and "Ka" (older man), are titles of respect reserved for older people. If one were to translate these titles into English, "Nana," can be loosely translated as "Maam," and "ka," translated as "Sir" or the title "Mr." But the effect comes out totally different from their original meaning. True, "Nana" and "Ka" are titles of respect, but a sense of intimacy and familiarity is also intimated in their use, which the English counterparts like "Maam" or "Sir," fail to render by their terseness and formality. I, as the postcolonial translator, thus, deemed it wise to keep such honorifics for their broad implications in showing the IlocanoHawaiian particularities and nuances of meaning. Moreover, keeping these Ilocano honorifics in the translation gives the readers a glimpse of some social protocols among the Filipinos, specifically the Ilocanos. Through the practice of using honorifics, the reservation and distance accorded to strangers among the Ilocanos collapse. Moreover, while honorifics distinguish age difference, their use collapses differences in social status between and among the Ilocanos. Their deployment seem to establish a bond amongst the Ilocanos since they serve not just to distinguish age difference and hierarchies, but they too serve as terms of endearment and have the effect of establishing familiarity between and among strangers.

The stories translated also contain some Ilocano words and expressions that defy translation into English. Some of these words are the following: "agbibisin," "apo balikbayan," “yad-adayom apo." These words are kept not only because of their untranslatability but are idiosyncratic to Ilocano culture. Translated loosely, the word/expression "agbibisin" is spoken of a person who has aspirations for a better status but the speaker sees through the posturing and affectation, thus, denoting some derogatory inflection. We see here an attitude or behavior that the Ilocanos give importance to. It is not so much ambition and arrogance that are given a high regard but humility and sincerity of character are some values worth emulating.

Often, third world writings and translations tend to exhibit an overzealous explanation of the source language. But by not offering a translation that would approximate the source language, the receiving audience is impelled to interpret and to locate the meaning of the source language based on some clues of the

Kritika Kultura 24 (2015): -261 
story. The expression "yad-adayom apo" is an interjection, loosely translated, it means, "God forbids!" Insisting on an English translation to these words could distort their meanings and misrepresentation. The non-Ilocano readers, therefore, are challenged to understand and locate what they mean. This reverses the table. Keeping these "untranslatables" renders the translated work a sense of the "foreign" (Maier, "Interviewing Carol Maier"). Though these are short, seemingly negligible expressions, their very foreignness can be unsettling. Keeping these Ilocano idioms, instead of saying, "God forbids," "heaven forbid," or "oh my God!" can have a certain subtle power as they can be deployed as "foreignizing strategy" in the translation. This, in turn, can slow down and estranges the rendering of the reading of the translation.

The expression "apo balikbayan" speaks of a new respect accorded to a returning (balikbayan) son or daughter from a sojourn abroad. The word "apo" is used as a formal address for a person of higher position, such as "apo mayor" (translated loosely, Mr. Mayor or sir mayor), or to a highest being, "Apo Dios" (God). Appending "apo" to balikbayan-“apo balikbayan" — sees the returnee with a new respect and new awe. Although the writings dramatize the nostalgia for home, every Ilocano dreams of going abroad, of going to America for a visit. The expression "apo balikbayan" implicitly captures the notion that America is a "land of milk and honey" the "land of opportunity" and that the Ilocano who has gone to America for various reasons has gained not just a modicum of wealth and success but has gained some experience borne out of travel, and therefore, the former has gained more experience relative to those who have not gone outside the Philippines, thus the awe and new respect for the returning townsmate. Moreover, the awe and respect accorded to the "apo balikbayan" speaks of the latter's coming out unscathed from the experience of a strange culture, past the "culture shock."Again, we see some positive notions the Ilocanos (supposedly by those from back home) hold about the US, but which is brought into question and opposition by the pressures and hostile US immigration policies and regulatory norms that the Ilocano immigrant has to contend with. Such positive notions may have been contributed by the Balikbayan Program (Homecoming) launched in 1973 by the Department of Tourism. This program has been put up to boost tourism in the Philippines. It targeted overseas Filipinos, including citizens or permanent residents of other countries (Executive Order No 657). In order to lure the Filipino American balikbayan to visit the Philippines, attractive privileges were offered to the balikbayan or the returnee. Some of them are the following: "1. Visa-free entry and a maximum stay of one year for foreign passport holders; 2. Tax-free purchase of goods at Philippine-free shops; and, 3.Travel tax exemptions" ("Balikbayan Program of the Philippines"). The expression "apo balikbayan" has a whole history and narrative to it and cannot simply be elided.

Kritika Kultura 24 (2015): -261

(C) Ateneo de Manila University

<http://kritikakultura.ateneo.net> 
In "The Seaweed Pickers," Consuelo, the protagonist, is given to rumination. In one of her ruminations, she laments over the disidentification of Filipino values (used metaphorically and metonymically as "Maria Clara") among the younger generation, as exemplified in her kids. In the source text, the paragraph simply ends with Manang Consuelo bewailing over the disappearance of these "Maria Clara" values. Since the original story is addressed to the Ilocano speaking community, it assumes that the term Maria Clara would be familiar to the readers, and thus, its elaboration would not be necessary. But in my translation, I thought that some elucidation was needed, as the receptor language is English. Hewing to the original text, the translation runs this way:

\begin{abstract}
Manang Consuelo is suddenly suffused with weakness, helpless over the bad company her kids have gotten into. She notes how people are by nature weak. Many have given in to the calling of the flesh. The locals have now come to identify with modern values. What has happened to our traditional Maria Clara values, she asks herself. . . (Translated from "Dagiti Agpidpidut iti Limo" 43)
\end{abstract}

The postcolonial lens necessitated an explanation of the Maria Clara values and that an elaboration of the term should be appended or added in the translation of the source text, mindful though, that no authorial imposition is transgressed in the translation. The explanation appended in the translation runs this way:

Manang Consuelo is suddenly suffused with weakness, helpless over the bad company her kids have gotten into. She notes how people are by nature weak. Many have given in to the calling of the flesh. The locals have now come to identify with modern values. What has happened to our traditional "Maria Clara" values, she asks herself. She recalls how her parents have deeply instilled in her these Maria Clara values-the value of propriety, chasteness, modesty, and decency. These values are no longer observed among our youth today, and Manang Consuelo laments this loss. In her days it was becoming for a Filipina to nurture such Maria Clara values. (emphasis added) (Translated from "Dagiti Agpidpidut iti Limo" 45)

This decision to give a brief explanation of "Maria Clara" values is meant to elucidate meaning for non-Ilocano readers. The appended explanation is informed on three counts: First, the target readers are enabled a clearer understanding of what they are, thereby, foregrounding an aspect of Filipino culture in the consciousness of the target audience. Second, I, as the translator, an Ilocano, understand the centrality of the Maria Clara values for the Ilocano-Hawaiian diasporic community. This value and everything it connotes is associated with the originary motherland. For the Ilocano immigrants, anything that is associated with the Motherland is deemed desirable. Third, I thought it necessary to append a brief explanation of these traditional Maria Clara values to illustrate that these so-called modern values 
of the West, which the protagonist (Manang Consuelo), recognizes as responsible for the third generation Fil-American's disidentification of Filipino values and ideals. These so-called modern American values have supplanted the traditional Maria Clara values. Finally, the explanation worked at insidiously foregrounding a specific Filipino cultural ideal. A short elaboration of the meaning of Maria Clara values is meant to juxtapose it with the modern, western values, illustrating not just the hierarchy of values in the social world of the Ilocano-Hawaiian community, in which the set of latter values are deemed the "ideal," but their faithfulness and identification to Filipino values.

A convention of narrative writing in English is the use of past tense. I, on the other hand, decided to employ the present tense for the following reasons: First, this would be in keeping with the tense used in the original, that is, the present tense (at least for the three stories translated). Second, I felt that the use of past tense would bring some awkward formulations and phraseologies in the translation. For example, in "The Seaweed Pickers," the narrator raves over the steadfastness of the sea. Since the subject is about the elemental character of the sea, the use of past tense would negate this observation; on the other hand, the use of present tense gets to capture the sense of the sea's eternal presence.

The sea in all its strange fluxes and oscillations is a stolid observer, taking in inexorably, the sea's vacillating elements, rhythm, texture, and hues. Hawaii has glorious mornings

... (Translated from "Dagiti Agpidpidut iti Limo" 43)

Although the decision to use the "present tense" form in the translation, departing from the "past tense" form as a common convention of narration in stories written in English, it is not that openly discernible or overt as compared to my other translation decisions. The decision to keep the present tense form as a convention of Ilocano-Hawaiian narration, ultimately circumvents or subverts a dominant convention of western standard of story-telling. The readers are not only yielded an understanding of the specificities of the Ilocano-Hawaiian diasporic writing but positions the Ilocano language at the "threshold of untranslatable" (Mehrez 122).

Another characteristic of GUMIL-Hawaii writing is keyed towards a sloweddown pace of narration, approximated through several repetitions of incidents (several episodes of the verbal clash between the siblings in "The Tang of Yesterday's Rain,"the replication of Nana Sela's under grip of nostalgia and her attempts at renegotiating this emotional ailment, and thirdly, several instances illustrating of Manang Consuelo's struggle with her American-like children and her lamentations over the disappearance of Maria Clara values). Unlike English stories which tend to unravel quickly, ${ }^{4}$ the three stories take a slower, more deliberate storytelling pace and moving towards their eventual unfolding to finish. The incidents are usually repeated before winding up to a conclusion. Such use of convention is meant to 
build up consistency of actions, thoughts, or feelings, climbing to a climax. The replication of incidents probably functions to build consistency, rendering a closure that is true to the facts of the story and therefore, a sense of arriving at a truth is made more palpable. Keeping the structure of the original in my translation departs from the usual way of story-telling in English, in turn, bringing into consciousness a different way of telling a story.

Ilocano lexicograph with its "preternaturally poetic" character, as deployed in the stories can be extremely difficult to translate. Such lexical difference may yield a translation that would not be quite in keeping with the sentiment or even the pathos of the story. If one doesn't heed the complexities of the language, the translation into English might come out excessive, which in turn, could lead to the misrepresentation not only of the source text but of the Ilocano-Hawaiian culture, given both the overdetermined and elusive character of language and meaning. Confronted with such difficulties, the translation decision hewed towards the simplicity of rendering. This, in turn, succeeded in evoking a sense of poignancy to the story. This translation decision is illustrated in "The Heaven of Nana Sela":

Adda dagiti kanito a kellaat lattan a rumtab ti lagipna kadagit napanawanna idiay Filipinas. Isu a rumtab ti lagipna a makaawid iti daytoy a tawen, ta uray la no sumagmamano nga aldaw ti pannakiinniliwna, umanayto manen a liwliwananga agsubli ditoy Hawaii. (Halaba 16)

Nostalgia grips her. "If only I could go home for a short visit . . . this would be enough bliss to make my Hawaii sojourn more bearable," Nana Sela sighs to herself. (translated from “Ti Languit ni Nana Sela” 16)

In as much as the goal of my translation is to address non-Ilocano readers, the translation act took on a conscious act of retaining the Ilocano-Hawaiian diasporic culture, materiality, and language. While the short stories are written in a classic, formal, preternaturally poetic Ilocano language, such formal register is symptomatic of an attempt to approximate an Ilokandia past, a memory (given the impossibility of return as time and history have intervened), revisited through the writings. The translation, therefore, approximates the formal, poetic rendering as illustrated in the following lines and instances in the three stories.

In “The Tang of Yesterday's Rain,” Manuel, the protagonist cannot contain his excitement over the thought of going home to the Philippines for a short visit. The days before his departure were filled with anticipation:

Manuel cannot suppress a smile as he maneuvers his car into the entrance of Ewa Beach.

His heart is full at the prospect of finally being able go home to the Philippines. After two

Kritika Kultura 24 (2015): -261

(C) Ateneo de Manila University

<http://kritikakultura.ateneo.net> 
years in Hawaii, he is finally going home. His papers are in order and he doubts if anyone could detain his trip. He is scheduled to fly in three days time.

Even before he is physically back, he is already in his beloved country of birth. In his mind, he sees the places he used to frequent back home. Running in his mind is the Pagsan River, his favorite fishing haunt. He wonders whether fish still abounds in his river. (Translated from "Naapgad ti Arbis idi Kalman" 66)

Sumsumrekken ti carro ni Manuel iti daramuangan ti Ewa Beach ngem di pay la limned ti isem a nabayagen a tumartaraigid kadagiti bibigna. Isem a nangparnuay iti aglaplapusanan a ragsak iti barukongna. Iti kamaudiananna, iti las-ud ti dua a tawen, makapagbakasion met laengen diay Fiipinas. Awanen ti makaigawid kenkuana. Nalpasen dagiti papeles na. Nabayadan ti pletena iti ahensia a nangasikaso iti panagawidna. Inton maikatlon a rabii ti tayabna. Iti napalaus a ragsak na, immunan a timmayab ti panunotna iti ili a nakaipasngayanna. Kasla makitkitanan ti ladawan ti lugar a naggapuannana. Ti napintas a buya ti karayan Pagsan nga inna pagkalkalapan sakbay nga immay iti Hawaii. Adu pay met la ngata ti lames a makalapan? (Ignacio 66)

In “The Seaweed Pickers," Manang Consuelo, the protagonist, is pursued by Ka Conrado, an Ilocano widower. She tries to stop herself from falling in love as this might not be the right time, but realizes that she might just yet be falling for the man. The sea is the setting of their love story.

Her heart throbs. The breeze wafts in a sweet- tangy smell of the sea. Some long-forgotten feelings stir within her. She feels like a young woman again.

A big wave rushes in, sweeping more seaweed into the shore. As they race to seize a cluster, their hands touch. Ka Conrado squeezes her hand, and Consuelo feels a warm rush at the pit of her stomach. A huge wave comes in again sweeping the pair into the shore. Consuelo is jolted into the realization that with him her problems are washed away. Conrado whispers something inher ears. Then before she knew it, she finds herself pinned around by strong arms. (translated from "Dagiti Agpidpidut ti Limo" 50)

Nagbaliw ti bang-I ti kadaratan ... nadlawna a kasla nagsubli iti kinabalasangna. Dimteng ti dalluyon a nangidaknir ti adu pay a limo. Nagtumpo, ng dagiti imada a nangtukma iti nalapsat a rannay. Sabali manen ti rikna ni Manang Consuelo. Kasla adda simmuknor iti kaungganna idi pislen ni Ka Conrado. Aglalo idi ibalikas manen ti lakay ti "ayayatenka, Connie!" 
Idi agpinnerrengda, kasla rimat ti init ti bigbigat dagiti matada. Simmabuag pay ti dalluyon. Iti isasagpatda iti kadaratan, kasla naidaknir amin a dagensen ni Manang Consuelo idi arasaasan ni Ka Conrado. Nadlaw laengen ni Manang Consuelo a nabaluden kadagiti takiag ti balo. (Yoro 50)

Nana Sela is suffused with nostalgia in "The Heaven of Nana Sela." The preternaturally poetic register is illustrated in this line:

Her longing for home grows more intense each day. She becomes more quiet, sadder. She tries to assuage this yearning for home by playing with her grandchildren and doing the household chores. She conceals her homesickness from Jim as Nana Sela doesn't want him to see that she is pining for home (translated from "Ti Languit ni Nana Sela 17).

Madlaw ti kinaliday ni Nana Sela bayat ti pinaglabas ti aldaw. Saanen a matagtagari. Ngem yaw-awanna babaen to panangay-ayamna kadagiti apokkona. Dina kayat a madlaw ni Jim a naliday. (Halaba 17)

The formal rendering of the translation as shown in the examples above, is, however, undercut by the transliteration of the dialogue which takes on a different register and inflection. The translation yields an utterance that does not come off as one spoken by a native English speaker, but one that is unmistakably an Ilocano-English utterance, heavy with Ilocano inflection. For example, in the fight between Consuelo and Marina (another Ilocano seaweed picker) over trespassing of territories in the gathering of seaweed, Ka Conrado comes in to mediate. $\mathrm{He}$ chastises them through these lines: "Have you no shame, fighting over our only source of livelihood? For your information, no one owns this beach. Let us all share in the sea's bounty." Marina, in turn snaps back at Conrado: "Mind your own business old man, if you don't want to get buried in the sand, You are all bullshit!"

Another instance of this Ilocano English variety is illustrated in the following lines in "The Tang of Yesterday's Rain." Here, Lucy calls her husband for dinner: "Poldo, Poldo, go on and call the children. It's dinner time." In another example, Lucy calls the attention of Manuel for shutting the door quite loudly. She tells him: "Don Manuel, you have not shed a drop of sweat in building this house. You don't have any right to break down my door." In another line, Manuel calls out to her niece and nephew as he has some presents for them. In the translation, I retained the dialogue set in English, as the kids speak English. Manuel says: "Jerry, Nanette, yohoo! Come and meet Uncle. He has some toys for you."

In the conversation between the husband and wife in "The Heaven of Nana Sela," Tina persuades Jim to allow Nana Sela to visit the Philippines. She says: "Why don't you let Mother go home, poor one?" In another occasion, the conversation is still on the subject of allowing the old woman to go home. Tina lawyers for Nana Sela. 
This is what she tells Jim: "But Mother wants to go home this year, and she is not getting younger, one doesn't know what God has in store for us ... yadadayom apo!"

The translation straddles between two registers: the first one attempts at formal register that approximates the tone and language of the original Ilocano rendering. The second introduces the flavor and inflection of Ilocano English through the dialogue of the characters. Thus, one imagines an Ilocano-Hawaiian speaking. The translation elides the importance given to pure English, deemed as the standard English, and any infraction of it is considered bad English. It moves away from replicating the register and inflection of a native English speaker, instead, works at rendering a translation that resonates with Ilocano-English inflection and variety. Thus, the effect "estranges" and "defamiliarizes," bringing into one's attention the syncretic and hybrid character of the translation. The translation allows the emergence of a new space, an in-between space that is not uncontaminated but a product of the recuperation of two languages and registers, yielding a syncretic work that has resonance with the hybrid, diasporic condition of the IlocanoHawaiian immigrants.

Keeping the conventions and structure of the source text aims at circumventing Eurocentric or western-centric mode of writing and ways of seeing. In the final analysis, the translations of these selected Ilocano short fiction into English that are informed by postcolonial decisions have created a "new language" that resonates with the undulations, rhythm, and nuances of Ilocano-Hawaiian diasporic tenor, language, and culture. The feminized position of translation or its subservience to the original is a common notion. Translation, however, can be recuperated to yield not only vast possibilities but as a site to foreground the translator's agenda. Since the "interventionism of the translator is by no means gratuitous but solicited and oriented by the text itself" (Simon 26), the process of translation has the potential of opening the latter's immense possibilities. As Sherry Simon argues, it can be recuperated to "trouble structures of authority" (1). Expanding the focus of translation as a mere linguistic activity, or as an "act of reproduction, through which the meaning of a text is transferred from one language to another, ... but a reworking of meaning" (Simon 23) can open up the text to endless possibilities, one of which is "mistranslation." Finally, an understanding of the critical nature of translation can yield "a particularly rich terrain for the mapping of cross-influences, creating many points of entry for the translator" (Simon 24). The challenge for me as the translator is not to usurp the place of the writer, risking his disappearance, instead, it is to "clearly mark the presence of the translator within the text" (Simon 27), demonstrated in her foregrounding of the source text's partiality. Such agenda, subverts, in turn, the notion of translation's dubiousness and the injunction of the translation's faithfulness to the original.

Kritika Kultura 24 (2015): -261

(C) Ateneo de Manila University

<http://kritikakultura.ateneo.net> 


\section{AFTERWORD}

The postcolonial translation work of three Ilocano-Hawaiian short fiction is an attempt at foregrounding a peripheral minority writing. It offers a notion that Asian American and or Filipino/Ilocano-American identity and subjectivity, and by extension, Filipino/Ilocano American literature, is far from homogeneous. Cultural formations are not fixed and unchanging but come from somewhere. They are shaped by overdetermined historical, material, cultural, political practices, processes, and incommensurabilities of the times. The translations bring into our consciousness that the broader Asian American writings, specifically, IlocanoHawaiian writings are widely diverse, rich, varied, and marked by differences, precisely, because of the heterogeneity of races and ethnicities in the first instance, and second, are shaped by the force of the material imperatives that come into play. And as subjectivities are informed by histories, host of specificities and pressures of the diasporic space, vis-a- vis, the homogenizing impositions of US hegemonic norms, these, in turn, are responded to by the contestations, negotiations, and rearticulations made by different immigrant groups and ethnicities. Such fractal and heterogenous materialities are inevitably reflected and constituted in the writings.

Asian American and Filipino American ethnicities are vastly and widely different from each other. Filipino Americans are different from the Japanese Americans or the Chinese Americans or the Indian Americans. In the same way, the Filipino Americans are different in so many ways from their Filipino kababayan in the Philippines. But while Asian Americans, Filipino Americans or Ilocano-Hawaiians are constituted by different imaginaries and desirabilities, Asian American as a racial group and a singular entity can be refunctioned to serve as a unified force in contending with forces that may thwart the pursuit of an equitable cultural alternatives. Ilocano-Hawaiian writing and discourse are precisely recuperated to assert difference. The postcolonial translation of Ilocano-Hawaiian writing does not only aim at propelling Ilocano-Hawaiian institutional representation and visibility but opens up a space to rethink dominant notions of Asian American literature and what constitutes and encompasses the notion of a broadly-speaking "American" Literature and Writing. 


\section{Notes}

1. "The 1890 McKinley Tariff had been the impetus behind Hawaii's desire to be a part of the United States. It had cancelled the favored duty-free entry of Hawaiian sugar by admitting all foreign sugarfree; at the same time it did not grant Hawaii the 2 cents per pound compensation paid the mainland growers for accepting the Mckinley Tariff. Although the 1894 Wilson-Gorman Tariff eventually restored the duty on foreign sugar, the possibility of another bill like McKinley Tariff would wreck the Hawaiian sugar industry. Annexation seemed the best course for Hawaii." (See Ruben Alcantara, "Filipinos in Hawaii, The First 75 years, 1906-1981." Filipino Migration to Hawaii: A Commemoration Book. Honolulu: Hawaii-Filipino Specialty Publication,1981,27)

2. After several organizing attempts as one association, GUMIL Filipinas became the umbrella organization. It has taken a major role in the preservation, production, publication of books. The almost simultaneous formation of different GUMIL chapters on the provincial level is phenomenal. Today, GUMIL association has 18 big chapters in the country and 7 outside the Philippines. Like Bannawag, the different GUMIL chapters have served as an infrastructure in the growth and advancement of Ilocano Literature. (See Ma. Socorro Q. Perez, "Ilocano-Hawaiian Diaspora in GUMIL Hawaii Writing and the Discourse of Collective Cultural Public Performances." PhD Diss., U of the Philippines, 2012.)

3. As GUMIL Hawaii writings (writings in Ilocano language) are deemed commercial risk by presses and publishers in Hawaii, the Association undertakes its own printing of their anthologies. Most of GUMIL Hawaii anthologies had been printed in small presses in Laoag, Ilocos Norte, Philippines, then shipped backed to Hawaii for distribution. Since finding sources and funding GUMIL Hawaii activities such as seminar workshops for potential writers and the ensuing publication of anthologies of the writing competition winners can present a problem, the Association tried to resolve such plight by organizing popularity contests, such as Ms. GUMIL Hawaii competition. This popularity contest became an annual activity since it started in 1972 . The commitment of GUMIL Hawaii to serve as venue for developing writing talents of potential writers and the preservation and development of the Ilocano language, literature, and culture have served to propel the growth of Ilocano Literature and Ilocano-Hawaiian writing. (See Ma. Socorro Q. Perez, "Ilocano-Hawaiian Diaspora in GUMIL Hawaii Writing and the Discourse of Collective Cultural Public Performances." PhD Diss., U of the Philippines, 2012.)

4. The modern short story as propounded by Edgar Allan Poe is brief and must be read in one sitting, with a unique and singular effect and impression. 


\section{Works Cited}

Alcantara, Ruben. "Filipinos in Hawaii: The First 75 Years, 1906-1981." Filipino Migration to Hawaii: A Commemoration Book. Honolulu: Hawaii-Filipino Specialty, 1981. Print.

Alegado, Dean T. "The Filipino Community in Hawaii: Development and Change." The Filipino-American Experience in Hawaii. Ed. Jonathan Okamura, et. al. Honolulu: Department of Sociology, U of Hawaii at Manoa, 1991. Print.

Campomanes, Oscar V. "Filipinos in the US and their Literature of Exile." Discrepant Histories Translocal Essays on Filipino Culture. Ed. Vicente L. Rafael. Manila: Anvil, 1995. Print.

Cordova, Fred F. Filipinos: Forgotten Asian Americans: A Pictorial Essay, 1763-circa 1963. US Demonstration Project. Iowa: Kendall/Hunt, 1983. Print.

Dalisay, Jose Y. Jr. "The Filipino Short Story in English: An Update for the '9os" The Likhaan Anthology of Philippine Literature in English from 1900 to the Present. Ed. Gemino H. Abad. Quezon City: University of the Philippines Press, 1998. 139-146. Print.

Foronda, Marcelino A. "Recent Ilokano Fiction in Hawaii: A Study in Philippine American Cultural and Literary History." Bullalayaw: Antolohia Dagiti Nangabak iti Salip iti Sarita iti 1976-1977, GUMIL Hawaii. Eds. Pacita Saludes, et al. Quezon City: Maferson, 1978. xi-xliv. Print.

Gonzales, NVM and Oscar V. Campomanes." "Filipino American Literature." An Interethnic Companion to American Literature. Ed. King-Kok Cheung. Los Angeles: Cambridge UP, 1997. Print.

Hagedorn, Jessica. "Introduction." Charlie Chan is Dead 2: At Home in the World: An Anthology of Contemporary Asian American Fiction. Ed. Jessica Hagedorn. New York: Penguin, 2003. xxviii- xxxii. Print.

Halaba, Pelagio. "Ti Langit ni Nana Sela” [The Heaven of Nana Sela]. Dawa. Eds. Francisco Ponce et. al. Honolulu: GUMIL Hawaii, 1989. 13-19. Print.

Hall, Stuart. "Cultural Identity and Diaspora." Colonial Discourse \& Postcolonial Theory: A Reader. Eds. Patrick Williams and Laura Chrisman. London: Harvester Wheatsheaf, 1993. 392- 403. Print.

Ignacio, Artemio. "Naapgad ti Arbis idi Kalman" [The Tang of Yesterday's Rain]. Dawa. Eds. Francisco Ponce et al. Honolulu: GUMIL Hawaii, 1989. 66-72. Print.

"Interviewing Carol Maier: A Woman in Translation." Quaderno. Revista de traduccio 2. 1998. Web. 10 Jan. 2015.

Kravetz, Erlinda V. "Writer's Note." Philippine American Short Stories: A Collection of Prize Winning Fiction in the PALM Council Philippine American Short Story Contest, 1989-1991. Quezon City: Giraffe Books, 1997. ix. Print.

Maier, Carol. "Toward a Theoretical Practice for Cross Cultural Translation." In Between Languages and Culture. Pittsburg: U of Pittsburg P, 1995. 21-38. Print.

Mehrez, Samia. "Translation and the Postcolonial Experience: The Francophone North African Text." Rethinking Translation: Discourse, Subjectivity, Ideology. Ed. Lawrence Venuti. New York: Routledge, 1992. Print. 
Ortega, Julio. "Epilogue: Migrations." Sudden Fiction Latino: Short Short Stories from the United States and Latin America. Ed. Robert Shepard and James Thomas. New York: W.W. Norton \&Company, 2010. 289-296. Print.

Peñaranda, Oscar. In Marcelino Foronda's "Recent Ilokano Fiction in Hawaii: A Study in Philippine American Cultural and Literary History." Bullalayaw: Antolohia Dagiti Nangabak iti Salip iti Sarita iti 1976-1977, GUMIL Hawaii. Eds. Pacita Saludes et al. Quezon City: Maferson, 1978. xi- xliv. Print.

Perez, Ma. Socorro Q. "Ilocano-Hawaiian Diaspora in GUMIL Hawaii Writing and the Discourse of Collective Cultural Public Performances." PhD Diss. U of the Philippines, 2012. Print.

Republic of the Philippines. Department of Tourism. Balikbayan Program of the Philippines. 24 Jan. 2015. Web. 7 Feb. 2015.

San Juan, Epifanio, Jr. "The Filipino Worker-Writer in America: An Introduction to Carlos Bulosan." New York: Peter Lang, American University Studies, Series III, Comparative Literature, Vol. 22, 1992. 133-191], Print.

---. "Filipino Writing in the United States: Reclaiming Whose America?" The Likhaan Book of Philippine Criticism (1992-1997). Ed. J. Neil Garcia. Quezon City: U of the Philippines P, 200o. 441-464. Print.

Simon, Sherry. "Taking Gendered Positions in Translation." Gender in Translation.

New York: Routledge, 1996. 1-35. Print.

Teodoro, Luis, Jr., ed. Out of this Struggle. Honolulu: UP of Hawaii, 1981. Print. "The Shaping of Modern Hawaiian History: Hawaii Today and Tomorrow." Unit V. Honolulu: Hawaii Multicultural Project, 198o. Print.

"The 1965 Immigration Act: Asian Nation Asian American History: Demographics and Issues." 17 April 2009. Web. Jan. 31. 2012.

Tiongson, Antonio T., Jr. "Introduction: Critical Considerations." Positively No Filipinos Allowed. Eds. Antonio Tiongson Jr., et al. Philadelphia: Temple U P, 20o6. 1-14. Print.

Tymoczko, Maria. "Postcolonial Writing and Literary Translation." Postcolonial Translation. Ed. Susan Bassnett and Harish Rivedi . New York: Routledge, 1999. 19-40. Print.

--.. "Introduction." Translation and Power. Ed. Maria Tymoczko and Edwin Gentzler. Massachusetts: U of Massachusetts P, 2002. 244-246. Print.

--. "Translation in Postcolonial Context." Changing the Terms: Translating in The Postcolonial Era. Eds. Sherry Simon and Paul St. Pierre. Ottawa: U of Ottawa P, 200. 147-151. Print.

Venuti, Lawrence. "Introduction." Rethinking Translation: Discourse, Subjectivity, Ideology. Ed. Lawrence Venuti. London and New York: Routledge, 1992. 1-17. Print.

Yoro, Amado. "Dagiti Agpidpidut iti Limo" [The Seaweed Pickers]. Dawa. Eds. Francisco Ponce et al. Honolulu: GUMIL Hawaii, 1989. 42-50. Print. 
Kritika Kultura 24 (2015): -261

(c) Ateneo de Manila University

<http://kritikakultura.ateneo.net> 
Kritika Kultura 24 (2015): -261

(c) Ateneo de Manila University

<http://kritikakultura.ateneo.net> 
Kritika Kultura 24 (2015): -261

(c) Ateneo de Manila University

<http://kritikakultura.ateneo.net> 
Kritika Kultura 24 (2015): -261

(c) Ateneo de Manila University

<http://kritikakultura.ateneo.net> 
